\title{
2,2'-Bis(4-benzoylphenoxy)biphenyl: A Novel Efficient Acyl-acceptant Monomer Yielding Wholly Aromatic Polyketones via Friedel-Crafts Type Polymerization with Arenedicarbonyl Chloride
}

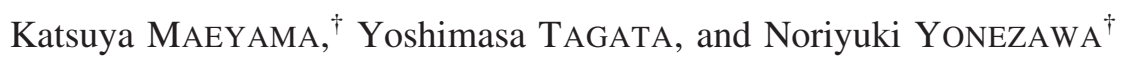 \\ Department of Organic and Polymer Materials Chemistry, Tokyo University of Agriculture and Technology, \\ Koganei, Tokyo 184-8588, Japan
}

(Received October 1, 2003; Accepted November 18, 2003)

\begin{abstract}
The biphenyl derivative having two benzoylphenoxy groups at 2,2'-positions (1), is proved to be an efficient acyl-acceptant monomer for $\mathrm{AlCl}_{3}$-mediated Friedel-Crafts acylation polymerization. Diaroylation of biphenyl 1 with 4-chlorobenzoyl chloride (2a) in the presence of $\mathrm{AlCl}_{3}$ readily proceeds with continuous reactivity and high regioselectivity at 5,5'-positions to give the diaroylated biphenyl (3a) in good yields. Further, polymerization of monomer 1 with several arenedicarbonyl chlorides $(\mathbf{4 a}-\mathbf{c})$ affords the corresponding wholly aromatic polyketones $(\mathbf{6})$ with high molecular weights. These wholly aromatic polyketones are soluble in various organic solvents such as chloroform, THF, and so on. The superior heat resistibility of the resulting polyketones $(\mathbf{6})$ is probably attributed to their characteristic polymer structures, i.e., all of the carbons involved in the polymer molecules have $\mathrm{sp}^{2}$ hybrid orbitals.

KEY WORDS 2,2'-Bis(4-benzoylphenoxy)biphenyl / Novel Acyl-Acceptant Monomer / FriedelCrafts Acylation Polymerization / Thermal Resistibility /
\end{abstract}

There are only a few reports on the synthesis of wholly aromatic polyketones, i.e., aromatic polyketones where no ether linkages are included in the main chains. ${ }^{1,2}$ Recently, we have succeeded in the synthesis of wholly aromatic polyketones via electrophilic aromatic substitution polymerization ${ }^{3-7}$ and via nickel complex-mediated aromatic coupling polymerization. ${ }^{8-10}$ As the ketonic carbonyl groups deactivate the arene rings against electrophilic aromatic substitution, electrophilic aroylation polycondensation between arenes and arenedicarboxylic acids is substantially difficult. For this reason, to perform polymerization in such manner especially needs activation of the intermediating aroylated arene in a unique fashion. During the course of our synthetic study on wholly aromatic polyketones, it has been disclosed that 2,2'-dimethoxybiphenyl is an excellent acyl-acceptant monomer having continuous reactivity and high regioselectivity in $\mathrm{AlCl}_{3}$-mediated FriedelCrafts-type polymerization. In 2,2'-dimethoxybiphenyl molecule, the properly situated methoxy groups activate the biphenyl electrically sufficiently, preventing the electrical deactivation of the still non-substituted aryl group in the biphenylene unit. These methoxy groups also make the dihedral angle between two aromatic rings in biphenylene unit suitably twisted, restraining the aggregation to precipitate the oligomeric intermediates in the early stage of polymerization. The resulting polyketone holds its weight constant till $450{ }^{\circ} \mathrm{C}$ in nitrogen and it starts to decompose about this temperature. Probably, scission of $\mathrm{sp}^{3}$ carbon- oxygen bond of 2,2'-dimethoxybiphenylene units occurs at the temperature. ${ }^{6}$ On the basis of such consideration, we have planned the improved molecular designing by exhaustive exclusion of $\mathrm{sp}^{3}$ carbon-oxygen bond from the polymer backbone. In this course, change of the repeating units from $2,2^{\prime}$-dimethoxybiphenylene units into 2,2'-diaryloxybiphenylene ones has been undertaken. As the aryloxy unit introduced alternately, we have a choice of 4-benzoylphenoxy group based on the following consideration: 1) electron-donating effect of two aryloxy groups situated at 2,2'-positions favors sustainable and regioselective electrophilic aromatic acylation on both phenylene rings in the biphenylene units and 2) introduction of the electron-deficient groups, i.e., aromatic ketonic groups, onto the phenoxy units in the side chains suppresses electrophilic aromatic substitution on the side chains.

In this paper, we would like to report the preparation of 2,2'-(4-benzoylphenoxy)biphenyl (1) and $\mathrm{AlCl}_{3}$-mediated Friedel-Crafts type acylation polymerization of the biphenyl (1) with arenedicarbonyl chlorides to afford wholly aromatic polyketones with high thermal resistibility.

\section{EXPERIMENTAL}

\section{General \\ ${ }^{1} \mathrm{H}$ NMR spectra were recorded on a JEOL JNM- A500 $(500 \mathrm{MHz})$. Chemical shifts are expressed in ppm relative to internal standard of $\mathrm{Me}_{4} \mathrm{Si}(\delta, 0.00)$.}

${ }^{\dagger}$ To whom correspondence should be addressed (Tel: +81-42-388-7475/7053, Fax: +81-42-381-7979, E-mail: maeyama@cc.tuat.ac.jp). 
${ }^{13} \mathrm{CNMR}$ spectra were recorded on a JEOL JNMA500 $(125 \mathrm{MHz})$. Chemical shifts are expressed in ppm relative to internal standard of $\mathrm{CDCl}_{3}(\delta, 77.0)$. IR measurement was recorded on a JEOL FR/IR5300. Gel permeation chromatography (GPC) measurements were carried out at a flow rate of $1.0 \mathrm{~mL} \mathrm{~min}^{-1}$ at $40{ }^{\circ} \mathrm{C}$ using $\mathrm{CHCl}_{3}$ as an eluent on a Shimadzu SPD-6A equipped with a UV detector $(340 \mathrm{~nm})$ and a Shodex GPC KD-806M column. Inherent viscosities $\left(\eta_{\text {inh }}\right)$ were determined in a concentrated $\mathrm{H}_{2} \mathrm{SO}_{4}\left(0.3 \mathrm{~g} \mathrm{dL}^{-1}\right)$ solution at $30^{\circ} \mathrm{C}$ using an Ostwald viscometer. Glass transition temperatures ( $T_{\mathrm{g}}$ 's) were determined on the basis of DSC curves. DSC curves were recorded on a SEIKO DSC-200 differential scanning calorimeter with a heating rate of $10 \mathrm{~K} \mathrm{~min}^{-1}$ under nitrogen. Thermal degradation temperatures $\left(T_{\mathrm{d}}\right)$ were determined on the basis of a TGA thermogram. The TGA thermogram was recorded on a SEIKO TG/DTA-200 thermogravimeter with a heating rate of $10 \mathrm{~K} \mathrm{~min}^{-1}$.

\section{Preparation of 2,2'-Bis(4-benzoylphenoxy)biphenyl 1}

To a two-necked flask, 4-fluorobenzophenone ( $5 \mathrm{mmol}, 1.0 \mathrm{~g}), 2,2^{\prime}$-biphenol (2.5 mmol, $\left.0.46 \mathrm{~g}\right)$, and potassium carbonate $(7.5 \mathrm{mmol}, 0.93 \mathrm{~g})$ were placed. Toluene $(10 \mathrm{~mL})$ and $N, N$-dimethylacetamide $(10 \mathrm{~mL})$ were added to the flask. The mixture was refluxed for $24 \mathrm{~h}$. After reflux, the reaction mixture was poured into $5 \mathrm{wt} \%$ sodium hydroxide solution dropwise and the mixture was extracted with $\mathrm{CHCl}_{3}$ three times. The combined extracts were washed with water and dried over anhydrous sodium sulfate. The solvent was removed under reduced pressure. The residue was purified by recrystalization from methanol.

IR $v(\mathrm{KBr}): 1655,1599,1501,1233 \mathrm{~cm}^{-1}$. ${ }^{1} \mathrm{H}$ NMR $(500 \mathrm{MHz}) \delta\left(\mathrm{CDCl}_{3}\right): 6.86(4 \mathrm{H}, \mathrm{d}, J=9.0 \mathrm{~Hz})$, $7.04(2 \mathrm{H}, \mathrm{dd}, J=2.8,8.0 \mathrm{~Hz}), 7.19(2 \mathrm{H}, \mathrm{d}, J=$ $8.0 \mathrm{~Hz}), 7.32(2 \mathrm{H}, \mathrm{dt}, J=2.0,7.5 \mathrm{~Hz}), 7.42(6 \mathrm{H}, \mathrm{dd}$, $J=2.0,8.0 \mathrm{~Hz}), 7.52(2 \mathrm{H}, \mathrm{t}, J=7.5 \mathrm{~Hz}), 7.67-7.70$ $(8 \mathrm{H}, \mathrm{m})$ ppm. ${ }^{13} \mathrm{CNMR} \quad(125 \mathrm{MHz}) \delta\left(\mathrm{CDCl}_{3}\right)$ : $117.1,120.0,120.4,128.1,129.3,129.6,130.0$, $131.6,132.0,132.1,132.2,137.8,153.0,161.3$, 195.3 ppm. Anal. Calcd. for $\mathrm{C}_{38} \mathrm{H}_{26} \mathrm{O}_{4}$ : C, $83.50 \%$; H, $4.79 \%$. Found: C, 83.74\%; H, $5.02 \%$.

\section{$\mathrm{AlCl}_{3}$-mediated Friedel-Crafts Type Acylation Poly- merization}

Acyl-acceptant monomer 1 (0.4 mmol, $218 \mathrm{mg})$ and arenedicarbonyl dichloride $\mathbf{4 a}-\mathbf{c}(0.4 \mathrm{mmol})$ were placed to a two-necked flask under nitrogen atmosphere. To the flask, 1,2-dichloroethane $(2.0 \mathrm{~mL})$ was added with a syringe. $\mathrm{AlCl}_{3}(3.6 \mathrm{mmol}, 480 \mathrm{mg})$ was added by portions to the solution. The reaction mixture was stirred for $1 \mathrm{~h}$ at $5^{\circ} \mathrm{C}$, warmed up to $15^{\circ} \mathrm{C}$, and stirred further for $24 \mathrm{~h}$ at $\mathrm{RT}$. The reaction was quenched by addition of methanol to separate out white precipitates. The precipitates were collected by suction filtration and dried in vacuo at $120^{\circ} \mathrm{C}$ to give a white solid of polymer $\mathbf{6 a}-\mathbf{c}$.

Polyketone 6a. IR v (KBr): 1657, 1589, 1493, $1252 \mathrm{~cm}^{-1}$. ${ }^{1} \mathrm{HNMR} \quad(500 \mathrm{MHz}) \quad \delta \quad\left(\mathrm{CDCl}_{3}\right): 7.01$ $(4 \mathrm{H}, \mathrm{d}, J=8.0 \mathrm{~Hz}), 7.07(2 \mathrm{H}, \mathrm{d}, J=8.5 \mathrm{~Hz}), 7.43$ $(4 \mathrm{H}, \mathrm{t}, J=7.5 \mathrm{~Hz}), 7.55(2 \mathrm{H}, \mathrm{t}, J=6.5 \mathrm{~Hz}), 7.69$ $(4 \mathrm{H}, \mathrm{d}, J=8.0 \mathrm{~Hz}), 7.75(4 \mathrm{H}, \mathrm{d}, J=8.0 \mathrm{~Hz}), 7.82$ $(2 \mathrm{H}, \mathrm{dd}, J=1.0,8.5 \mathrm{~Hz}), 7.85(4 \mathrm{H}, \mathrm{s}), 8.01(2 \mathrm{H}, \mathrm{s})$ ppm. ${ }^{13} \mathrm{CNMR}(125 \mathrm{MHz}) \delta\left(\mathrm{CDCl}_{3}\right): 118.1,118.6$, $128.3,128.5,129.6,129.8,132.2,132.4,132.5$, $132.6,133.3,133.4,134.4,137.4,140.6,158.0$, 159.4, 194.1, $195.1 \mathrm{ppm}$. Anal. Calcd. for $\left(\mathrm{C}_{46^{-}}\right.$ $\left.\mathrm{H}_{28} \mathrm{O}_{6}\right)_{n}: \mathrm{C}, 81.64 \%$; H, $4.17 \%$. Found: C, $81.22 \%$; $\mathrm{H}, 4.12 \%$.

Polyketone 6b. IR v (KBr): 1657, 1595, 1493, $1238 \mathrm{~cm}^{-1}$. ${ }^{1} \mathrm{HNMR}(500 \mathrm{MHz}) \delta\left(\mathrm{CDCl}_{3}\right): 6.99$ $(4 \mathrm{H}, \mathrm{d}, J=8.5 \mathrm{~Hz}), 7.03(2 \mathrm{H}, \mathrm{d}, J=8.5 \mathrm{~Hz}), 7.42$ $(4 \mathrm{H}, \mathrm{t}, J=7.0 \mathrm{~Hz}), 7.53(3 \mathrm{H}, \mathrm{t}, J=7.0 \mathrm{~Hz}), 7.68$ $(4 \mathrm{H}, \mathrm{d}, J=8.0 \mathrm{~Hz}), 7.73(4 \mathrm{H}, \mathrm{d}, J=8.5 \mathrm{~Hz}), 7.79$ (2H, d, $J=8.5 \mathrm{~Hz}), 7.95(2 \mathrm{H}, \mathrm{d}, J=7.5 \mathrm{~Hz}), 8.01$ $(2 \mathrm{H}, \mathrm{s}), 8.27(1 \mathrm{H}, \mathrm{s}) \mathrm{ppm} .{ }^{13} \mathrm{CNMR}(125 \mathrm{MHz}) \delta$ $\left(\mathrm{CDCl}_{3}\right)$ : 118.0, 118.7, 128.3, 128.5, 129.8, 132.4, $132.5,133.3,133.4,134.3,137.4,137.9,157.9$, 159.4, 194.0, $195.1 \mathrm{ppm}$. Anal. Calcd. for $\left(\mathrm{C}_{46^{-}}\right.$ $\left.\mathrm{H}_{28} \mathrm{O}_{6}\right)_{n}$ : C, $81.64 \%$; H, $4.17 \%$. Found: C, $81.47 \%$; $\mathrm{H}, 4.48 \%$.

Polyketone 6c. IR v (KBr): 1657, 1591, 1495, $1252 \mathrm{~cm}^{-1}$. ${ }^{1} \mathrm{HNMR}(500 \mathrm{MHz}) \quad \delta \quad\left(\mathrm{CDCl}_{3}\right): 7.02$ $(4 \mathrm{H}, \mathrm{d}, J=9.0 \mathrm{~Hz}), 7.09(2 \mathrm{H}, \mathrm{d}, J=8.5 \mathrm{~Hz}), 7.44$ $(4 \mathrm{H}, \mathrm{t}, J=7.5 \mathrm{~Hz}), 7.55(2 \mathrm{H}, \mathrm{t}, J=7.0 \mathrm{~Hz}), 7.70$ $(4 \mathrm{H}, \mathrm{d}, J=7.5 \mathrm{~Hz}), 7.76(4 \mathrm{H}, \mathrm{d}, J=8.5 \mathrm{~Hz}), 7.85$ $(2 \mathrm{H}, \mathrm{dd}, J=2.0,8.5 \mathrm{~Hz}), 7.89(8 \mathrm{H}, \mathrm{s}), 8.03(2 \mathrm{H}, \mathrm{s})$ ppm. ${ }^{13} \mathrm{CNMR}(125 \mathrm{MHz}) \delta\left(\mathrm{CDCl}_{3}\right): 118.0,118.7$, $128.3,128.5,129.8,132.4,132.5,133.3,133.4$, 134.3, 137.4, 137.9, 157.9, 159.4, 194.0, 195.1 ppm. Anal. Calcd. for $\left(\mathrm{C}_{53} \mathrm{H}_{32} \mathrm{O}_{7}\right)_{n}$ : C, 81.53\%; $\mathrm{H}$, $4.13 \%$. Found: C, $81.27 \% ; \mathrm{H}, 4.29 \%$.

\section{RESULTS AND DISCUSSION}

\section{Preparation of Acyl-acceptant Monomer 1}

The acyl-acceptant monomer, 2,2'-(4-benzoylphenoxy)biphenyl (1), was prepared via nucleophilic aromatic substitution reaction of 2,2'-biphenol and 4-fluorobenzophenone in the presence of potassium carbonate for $24 \mathrm{~h}$ in DMAc/toluene ( $84 \%$ yield).

\section{Reactivity of Acyl-acceptant Monomer 1}

We preliminarily investigated the reactivity of the resulting acyl-acceptant monomer (1) in the reaction with a monofunctional acyl donor compound. Table I shows the results of diaroylation of monomer $\mathbf{1}$ with 4-chlorobenzoyl chloride (2a) or 4-chlorobenzoic acid 
Table I. Reaction of 2,2'-bis(4-benzoylphenoxy)biphenyl (1) with $p$-chlorobenzoic acid derivatives ${ }^{\mathrm{a}}$

\begin{tabular}{cccccr}
\hline \multirow{2}{*}{ Run } & \multirow{2}{*}{$\mathbf{2} / \mathrm{mmol}$} & \multirow{2}{*}{ Reagent } & \multicolumn{2}{c}{ Temp. } & \multicolumn{2}{c}{ Yield $(\%)^{\mathrm{c}}$} \\
& & & $\left.{ }^{\circ} \mathrm{C}\right)$ & $\mathbf{3 a}$ & $\mathbf{3 b}$ \\
\hline $1^{\mathrm{b}}$ & $\mathbf{2 a} / 0.8$ & $\mathrm{AlCl}_{3}, 1.8 \mathrm{mmol}$ & $\mathrm{RT}$ & 0 & 63 \\
$2^{\mathrm{b}}$ & $\mathbf{2 a} / 0.8$ & $\mathrm{AlCl}_{3}, 3.6 \mathrm{mmol}$ & $\mathrm{RT}$ & 92 & 0 \\
$3^{\mathrm{b}}$ & $\mathbf{2 a} / 0.4$ & $\mathrm{AlCl}_{3}, 3.6 \mathrm{mmol}$ & $\mathrm{RT}$ & 13 & 72 \\
$4^{\mathrm{d}}$ & $\mathbf{2 b} / 0.8$ & $\mathrm{P}_{2} \mathrm{O}_{5}-\mathrm{MsOH} 1.4 \mathrm{~mL}$ & 120 & 50 & 50 \\
5 & $\mathbf{2 b} / 0.8$ & $\mathrm{P}_{2} \mathrm{O}_{5}-\mathrm{MsOH}, 1.4 \mathrm{~mL}$ & 120 & 52 & 48 \\
\hline
\end{tabular}

${ }^{\text {a}}$ Reaction conditions: biphenyl 1; $0.4 \mathrm{mmol}$, Reaction time; $24 \mathrm{~h}$. ${ }^{\mathrm{b}}$ Solvent, 1,2-dichloroethane; $2.0 \mathrm{~mL}$. ${ }^{\mathrm{c} 1} \mathrm{H}$ NMR yield. ${ }^{\mathrm{d}}$ Reaction time, $8 \mathrm{~h}$.

(2b). When 4.5 equimolar amounts of $\mathrm{AlCl}_{3}$ were subjected, the monosubstituted product $(\mathbf{3 b})$ was obtained chemoselectively and regioselectively (Run 1). Though the production of the monosubstituted product (3b) means low ability for the second aroylation of monomer 1, it has been solved by treatment of biphenyl 1 with 9 equimolar amounts of $\mathrm{AlCl}_{3}$ to give the disubstituted product (3a) as a single product in a high yield (Run 2). In this way, it has been disclosed that 2,2'-bis(4-benzoylphenoxy)biphenyl (1) has a sufficient reactivity for Friedel-Crafts diaroylation in the presence of excess $\mathrm{AlCl}_{3}$. On the contrary, direct condensation of biphenyl $\mathbf{1}$ with carboxylic acid $\mathbf{2 b}$ in $\mathrm{P}_{2} \mathrm{O}_{5}-\mathrm{MsOH}^{5,6,11-13}$ gave mixtures of monosubsituted and disubstituted products.

Polymerization of Acyl-acceptant Monomer 1 with Terephthaloyl Chloride

Table II shows the results of polymerization of $2,2^{\prime}-$ bis(4-benzoylphenoxy)biphenyl (1) with terephthaloyl chloride (4a) in the presence of $\mathrm{AlCl}_{3}$. Among solvents screened, 1,2-dichloroethane is the most suitable for this polymerization. The structures of the polyketones were confirmed on the basis of ${ }^{1} \mathrm{H}$ NMR spectra. The signal at $7.19 \mathrm{ppm}$ which is assignable to the protons at 5,5'-positions of monomer 1 clearly disappears in the ${ }^{1} \mathrm{H}$ NMR spectrum of the product. This indicates<smiles>O=C(c1ccccc1)c1ccc(F)cc1</smiles><smiles>CC(=O)Oc1ccccc1-c1ccccc1O</smiles><smiles>CC(C)(C)O</smiles>

Scheme 1.<smiles>O=C(c1ccccc1)c1ccc(Oc2ccccc2-c2ccccc2Oc2ccc(C(=O)c3ccccc3)cc2)cc1</smiles>

1

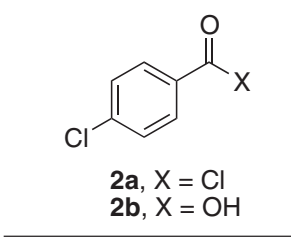<smiles>O=C(c1ccccc1)c1ccc(Oc2ccc(C(=O)c3ccc(Cl)cc3)c(-c3cc(P)ccc3Oc3ccc(C(=O)c4ccccc4)cc3)c2)cc1</smiles>

3a, $\mathrm{R}=p-\mathrm{ClC}_{6} \mathrm{H}_{4} \mathrm{CO}$ 3b, $\mathrm{R}=\mathrm{H}$

Scheme 2. 


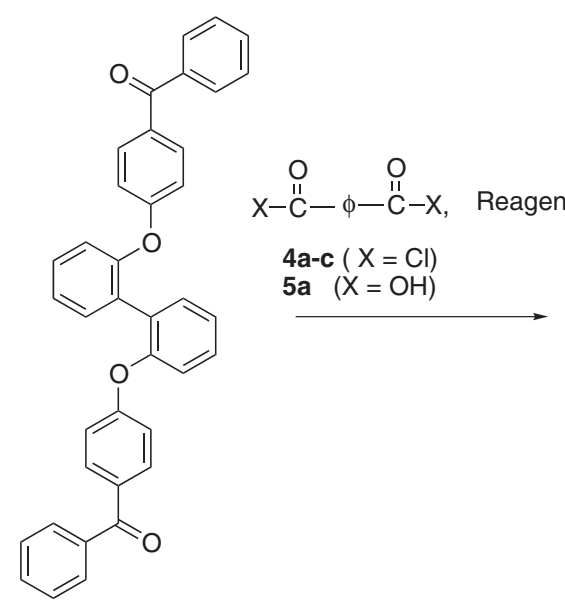

1

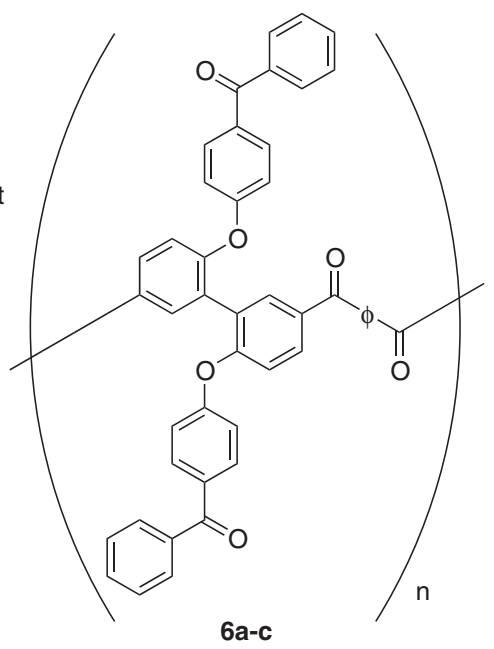

$\phi$
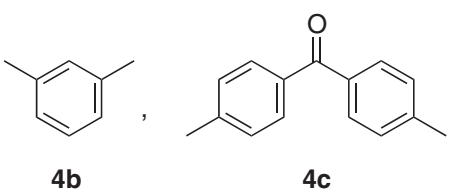

Scheme 3.

Table II. Polymerization of 2,2'-bis(4-benzoylphenoxy)biphenyl (1) with terephthalic acid derivatives $\mathbf{4 a} / \mathbf{5} \mathbf{a}^{\mathrm{a}}$

\begin{tabular}{ccccccc}
\hline Run & $\mathbf{4 a} / \mathbf{5 a}$ & Reagent/solvent & $\begin{array}{c}\text { Temp. } \\
\left({ }^{\circ} \mathrm{C}\right)\end{array}$ & $\begin{array}{c}\text { Time } \\
(\mathrm{h})\end{array}$ & $\begin{array}{c}\text { Yield } \\
(\%)\end{array}$ & $M_{\mathrm{n}}{ }^{\mathrm{b}}$ \\
\hline $1^{\mathrm{c}}$ & $\mathbf{4 a}$ & $\mathrm{AlCl}_{3} / \mathrm{ClCH}_{2} \mathrm{CH}_{2} \mathrm{Cl}$ & $\mathrm{RT}$ & 20 & 84 & 13000 \\
$2^{\mathrm{c}}$ & $\mathbf{4 a}$ & $\mathrm{AlCl}_{3} / \mathrm{ClCH}_{2} \mathrm{CH}_{2} \mathrm{Cl}$ & $\mathrm{RT}$ & 30 & 84 & 17000 \\
$3^{\mathrm{c}}$ & $\mathbf{4 a}$ & $\mathrm{AlCl}_{3} / \mathrm{C}_{6} \mathrm{H}_{5} \mathrm{NO}_{2}$ & $\mathrm{RT}$ & 20 & 0 & - \\
$4^{\mathrm{c}}$ & $\mathbf{4 a}$ & $\mathrm{AlCl}_{3} / \mathrm{CHCl}_{3}$ & $\mathrm{RT}$ & 20 & 83 & 3400 \\
$5^{\mathrm{d}}$ & $\mathbf{5 a}$ & $\mathrm{P}_{2} \mathrm{O}_{5}-\mathrm{MsOH}$ & 120 & 40 & 40 & 4000 \\
\hline
\end{tabular}

${ }^{a}$ Monomer 1, $0.4 \mathrm{mmol}$; terephthaloyl chloride (4a)/terephthalic acid (5a), $0.4 \mathrm{mmol} .{ }^{\mathrm{b}} \mathrm{Calibrated}$ on the basis of GPC curve (column: Shodex KD-806M. eluent: $\mathrm{CHCl}_{3}$. UV detector: $340 \mathrm{~nm}$.) ${ }^{\mathrm{c}} \mathrm{AlCl}_{3}, 3.6 \mathrm{mmol}$; Solvent, $2 \mathrm{~mL} .{ }^{\mathrm{d}} \mathrm{P}_{2} \mathrm{O}_{5}-\mathrm{MsOH}$, $1.2 \mathrm{~mL}$.

that regioselective dual aroylation at the 5,5'-positions of monomer $\mathbf{1}$, i.e., polymerization, proceeded. The resulting polyketone is soluble in $\mathrm{CHCl}_{3}$. Such solubility is distinct from that of 2,2'-dimethoxybiphenylene-containing polyketones we have already synthesized, which is soluble only in concentrated $\mathrm{H}_{2} \mathrm{SO}_{4}$. Further elongation of reaction time, however, incurs the precipitates during polymerization in 1,2-dichloroethane and the precipitates were insoluble even in trifluoroacetic acid and concentrated $\mathrm{H}_{2} \mathrm{SO}_{4}$. When reaction time was elongated to $60 \mathrm{~h}$, the component soluble in $\mathrm{CHCl}_{3}$ was only $2 \%$. On the other hand, there is no difference in IR spectra between the soluble and insoluble components. On the basis of these observations, insolubilization is possibly due to either high molecular weight or cross-linked structure.
Table III. Polymerization of 2,2'-bis(4-benzoylphenoxy)biphenyl (1) with arenedicarbonyl chloride $4^{\mathrm{a}}$

\begin{tabular}{cccccccc}
\hline Run & $\mathbf{4}$ & $\begin{array}{c}\text { Time } \\
(\mathrm{h})\end{array}$ & $\begin{array}{c}\text { Yield } \\
(\%)\end{array}$ & $M_{\mathrm{n}}{ }^{\mathrm{b}}$ & $\begin{array}{c}\eta_{\text {inh }} \\
\left(\mathrm{dL} \mathrm{g}^{-1}\right)^{\mathrm{c}}\end{array}$ & $\begin{array}{c}T_{\mathrm{g}} \\
\left({ }^{\circ} \mathrm{C}\right)\end{array}$ & $\begin{array}{c}T_{\mathrm{d}} \\
\left({ }^{\circ} \mathrm{C}\right)^{\mathrm{d}}\end{array}$ \\
\hline 1 & $\mathbf{4 a}$ & 30 & 84 & 17000 & 0.382 & 159 & 525 \\
2 & $\mathbf{4 b}$ & 60 & 72 & 12000 & 0.362 & 158 & 510 \\
3 & $\mathbf{4 c}$ & 60 & 75 & 15000 & 0.318 & 163 & 500 \\
\hline
\end{tabular}

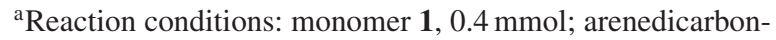
yl chloride 4, 0.4 mmol. $\mathrm{AlCl}_{3}, 3.6 \mathrm{mmol}, \mathrm{ClCH}_{2} \mathrm{CH}_{2} \mathrm{Cl}, 2 \mathrm{~mL}$. ${ }^{\mathrm{b}}$ Calibrated on the basis of GPC curve (column: Shodex KD806M. eluent: $\mathrm{CHCl}_{3}$. UV detector: $340 \mathrm{~nm}$.) ${ }^{\mathrm{c}}$ Determined in a concentrated $\mathrm{H}_{2} \mathrm{SO}_{4}$ solution $\left(0.3 \mathrm{~g} \mathrm{dL}^{-1}\right)$ at $30^{\circ} \mathrm{C}$. ${ }^{\mathrm{d}}$ Temperature where a $5 \mathrm{wt} \%$ weight loss was recorded by TG.

\section{Synthesis and Characterization of Wholly Aromatic Polyketones $6 \mathbf{a}-\boldsymbol{c}$}

Table III shows the results of the $\mathrm{AlCl}_{3}$-mediated polymerization of monomer 1 with other arenedicarbonyl chlorides $\mathbf{4 b}$ and $\mathbf{4 c}$. The same reaction behaviors were observed in the reaction of other dicarbonyl chlorides, yielding the corresponding polyketones. When isophthaloyl chloride (4b) was employed, elongation of reaction time incurred no precipitation of insoluble component but no further polymerization occurred. On the other hand, when 4,4'-benzophenonedicarbonyl chloride (4c) was allowed to react, a trace amount of the component insoluble to any solvent was obtained. As the structures of acyl chlorides 4a and $4 \mathbf{c}$ are probably stretched, the resulting polymers should be rigid and easy to separate out. On the contrary, the characteristically bent structures of $m$-phenylene units presumably results in high solubil- 
ity of the polyketones derived from isophthaloyl chloride $(\mathbf{4 b})$.

Polyketones $\mathbf{6 a - c}$ shows a $5 \%$ weight loss in the TGA thermograms under nitrogen at $c a .500^{\circ} \mathrm{C}$. These properties are superior to those of the $2,2^{\prime}$-dimethoxybiphenylene-containing wholly aromatic polyketones we have already reported. ${ }^{7}$ Probably, exclusion of $\mathrm{sp}^{3}$ carbon-oxygen bond raises heat resistibility. $T_{\mathrm{g}}$ 's of polyketones $\mathbf{6 a}-\mathbf{c}$ were determined to be $c a .160{ }^{\circ} \mathrm{C}$ on the basis of the DSC curves. These values are lower than those of 2,2'-dimethoxybiphenylene-containing wholly aromatic polyketones. ${ }^{3,7}$ In addition, any polyketones thus obtained showed no melting point.

\section{CONCLUSION}

2,2'-Bis(4-benzoylphenoxy)biphenyl (1) has an excellent acyl-accepting reactivity in electrophilic aromatic substitution so that high-molecular-weight wholly aromatic polyketones are readily yielded. The obtained polyketones show excellent solubility to organic solvents and have high heat resistibility.

\section{REFERENCES}

1. N. Yonezawa, J. Synth. Org. Chem. Jpn., 53, 172 (1995).

2. P. A. Staniland, "Comprehensive Polymer Science," G. C. Eastmond, A. Ledwith, S. Russo, and P. Sigwalt, Ed., Pergamon Press, Oxford, U.K., 1989, vol 5, p 483.

3. N. Yonezawa, S. Miyata, T. Nakamura, S. Mori, Y. Ueha, and R. Katakai, Macromolecules, 26, 5262 (1993).

4. N. Yonezawa, T. Namie, T. Ikezaki, T. Hino, H. Nakamura, Y. Tokita, and R. Katakai, React. Funct. Polym., 20, 261 (1996).

5. K. Maeyama, T. Namie, H. Nakamura, and N. Yonezawa, Recent Prog. Polycondens., 173 (2002).

6. N. Yonezawa, H. Nakamura, and K. Maeyama, React. Funct. Polym., 51, 19 (2002).

7. N. Yonezawa, S. Mori, S. Miyata, Y. Ueha-Anyashiki, S. M. Wu, and K. Maeyama, Polym. J., 35, 998 (2003).

8. N. Yonezawa, T. Ikezaki, H. Nakamura, and K. Maeyama, Macromolecules, 33, 8125 (2000).

9. K. Maeyama, T. Ohe, H. Nakamura, and N. Yonezawa, Polym. J., 35, 290 (2003).

10. K. Maeyama, T. Ohe, H. Nakamura, and N. Yonezawa, Polym. J., 35, 1009 (2003).

11. M. Ueda and M. Sato, Macromolecules, 20, 2675 (1987).

12. M. Ueda and M. Oda, Polym. J., 21, 673 (1989).

13. K. Maeyama, T. Ohe, H. Nakamura, and N. Yonezawa, Synth. Commun., in press. 